\title{
Life Cycle Assessment (LCA) Pengelolaan Sampah di TPA Gunung Panggung Kabupaten Tuban, Jawa Timur
}

\section{Life Cycle Assessment (LCA) of Municipal Solid Waste Management in Gunung Panggung Landfill, Tuban Regency, East Java}

\author{
RAHMAH ARFIYAH ULA ${ }^{1 *}$, AGUS PRASETYA ${ }^{2,3 *}$, DAN IMAN HARYANTO ${ }^{4}$ \\ ${ }^{1}$ Program Studi Ilmu Lingkungan, Minat Studi Teknologi untuk Pengembangan Berkelanjutan, \\ Sekolah Pascasarjana Universitas Gadjah Mada, 55281 \\ ${ }^{2}$ Departemen Teknik Kimia, Fakultas Teknik Universitas Gadjah Mada, Jln. Grafika 2 Yogyakarta, 55281 \\ ${ }^{3}$ Waste Refinery Center (WRC), Fakultas Teknik, Universitas Gadjah Mada \\ ${ }^{4}$ Departemen Teknik Sipil, Sekolah Vokasi Universitas Gadjah Mada, Yogyakarta, 55281 \\ Email: rahmahaarfiyah@gmail.com, aguspras@ugm.ac.id
}

\begin{abstract}
The primary municipal waste treatment in Tuban Regency, East Java, was landfilling, besides the small amount of the waste was turned to compost. Landfilling causes global warming, which leads to climate change due to $\mathrm{CH} 4$ emission. This environmental impact could be worst by the population growth that increases the amount of waste. This study aimed to evaluate the environmental impact on waste management in the Gunung Panggung landfill in Tuban Regency and its alternative scenarios using Life Cycle Assessment (LCA). Four scenarios were used in this study. They are one existing scenario and three alternative scenarios comprising landfilling, composting, and anaerobic digestion. The scope of this study includes waste transportation to waste treatment which is landfilling, composting, and anaerobic digestion $(A D)$. The functional unit of this analysis is per ton per year of treated waste. Environmental impacts selected are global warming potential, acidification potential, and eutrophication potential. The existing waste management in Gunung Panggung landfill showed the higher global warming potential because of the emission of CO2 and cost for human health, which is 6.379.506,17 CO2 eq/year and 5,92 DALY, respectively. Scenario 3 (landfilling, composting, and $A D$; waste sortation 70\%) showed a lower environmental impact than others, but improvements were still needed. Covering compost pile or controlling compost turning frequency was proposed for scenario 3 amendment.
\end{abstract}

Keywords: environmental impact, landfill, life cycle assessment, waste management

\section{ABSTRAK}

Landfill merupakan pengelolaan sampah utama di tempat pemrosesan akhir (TPA) Gunung Panggung Kabupaten Tuban. Selain landfill, pengomposan diterapkan untuk mengolah sebagian kecil sampahnya. Landfill menghasilkan gas metana yang menyebabkan pemanasan global dan memicu perubahan iklim. Pertambahan penduduk memperbanyak sampah yang perlu diolah di TPA dan dapat memperparah dampak lingkungan yang ditimbulkan. Tujuan penelitian ini adalah menilai dampak lingkungan dari pengelolaan sampah eksisting di TPA Gunung Panggung Kabupaten Tuban Jawa Timur beserta skenario alternatifnya menggunakan Life Cycle Assessment (LCA). Terdapat satu skenario eksisting dan tiga skenario alternatif pengelolaan sampah yaitu landfilling, pengomposan, dan fermentasi anaerob (anaerobic digestion). Ruang lingkup studi meliputi pengangkutan sampah, pengelolaan sampah dengan cara pengomposan, Anaerobic Digestion (AD), dan landfill. Satuan fungsional yang digunakan yakni ton sampah yang diolah per tahun. Dampak lingkungan yang dipelajari di antaranya: pemanasan global, asidifikasi, dan eutrofikasi. Dampak lingkungan skenario eksisting menunjukkan nilai tertinggi terutama pada pemanasan global (6.379.506,17 $\mathrm{CO}_{2}$ eq/tahun) dan kerugian pada kesehatan manusia (5,92 DALY). Skenario alternatif 3 , yang meliputi pengelolaan secara landfill, pengomposan, dan AD menunjukkan dampak lingkungan yang kecil, namun memerlukan perbaikan. Perbaikan untuk skenario 3 yaitu dengan menambahkan penutup pada tumpukan kompos atau mengontrol frekuensi pembalikan kompos untuk mengurangi emisi $\mathrm{NH}_{3}$.

Kata kunci: dampak lingkungan, life cycle assessment, pengelolaan sampah, tempat pemrosesan akhir

\section{PENDAHULUAN}

\subsection{Latar Belakang}

Kabupaten Tuban Provinsi Jawa Timur terletak antara $6,40-7,18^{\circ} \mathrm{LS}$ dan antara 111,30 $112,35^{\circ} \mathrm{BT}$. Hingga tahun 2018, jumlah penduduk di Kabupaten Tuban tercatat sebanyak 1.168.277 jiwa(1) dan akan semakin bertambah di masa mendatang. Pertambahan penduduk tentunya berpengaruh pada timbulan sampah yang 
terbentuk. Laju timbulan sampah tiap daerah dapat saja berbeda. Misalnya laju timbulan sampah untuk daerah terlayani TPA Jabon Sidoarjo tahun 2017 yaitu sebesar 0,43 $\mathrm{kg} /$ orang.hari(2), atau di Kecamatan Sukolilo Surabaya tahun 2017 sebesar 0,38 kg/orang.hari(3). Menurut Dinas Lingkungan Hidup Kabupaten Tuban, laju timbulan sampah di Kabupaten Tuban yakni 0,36 kg/orang.hari pada tahun 2018, dengan demikian dapat diasumsikan bahwa timbulan sampah di Kabupaten Tuban sebesar 420.579,72 kg/hari.

Sebagian sampah di Kabupaten Tuban berakhir di Tempat Pemrosesan Akhir (TPA) Gunung Panggung yang berada di Kecamatan Semanding, Kabupaten Tuban. TPA Gunung Panggung melayani enam kecamatan, yaitu Kecamatan Semanding, Kecamatan Palang, Kecamatan Tuban, Kecamatan Jenu, Kecamatan Merakurak, dan Kecamatan Widang, dengan luas total kecamatan terlayani 220,79 $\mathrm{km}^{2}$. Pengelolaan sampah di TPA Gunung Panggung utamanya adalah landfill. Terdapat enam sel, tiga di antaranya menggunakan sanitary landfill dan tiga sisanya menggunakan controlled landfill. Sebagian kecil dari sampah daun dimanfaatkan menjadi kompos, sekitar $0,0004 \%$ dari keseluruhan timbulan sampah di Kabupaten Tuban. Partisipasi masyarakat dalam hal pemilahan sampah dari sumber telah dilakukan, terwujud dalam aktivitas pemilahan sampah anorganik yang selanjutnya diserahkan ke bank sampah. Namun, jumlah bank sampah aktif di Kabupaten Tuban, khususnya daerah yang dilayani TPA Gunung Panggung masih sedikit, yakni 60 bank sampah. Sementara itu, pemilahan sampah organik belum dilakukan.

Pengolahan sampah dengan landfill mengemisikan gas rumah kaca $\left(\mathrm{CH}_{4}\right.$ dan $\left.\mathrm{CO}_{2}\right)$ yang dapat menyebabkan pemanasan global $^{(4)}$. Emisi gas rumah kaca yang dihasilkan dari pengolahan sampah dengan cara landfill dan pengomposan di TPA Winongo Kota Madiun dilaporkan sebesar 5.905,59 ton $\mathrm{CO}_{2}$ eq pada tahun 2015. Pengolahan dengan cara landfilling berkontribusi terhadap emisi $\mathrm{CH}_{4}$ sebesar 281,206 ton dan proses pengomposan berkontribusi terhadap emisi $\mathrm{CH}_{4}$ (6,278 ton) dan $\mathrm{N}_{2} \mathrm{O}(0,470 \text { ton })^{(5)}$. Sementara itu, penelitian mengenai emisi gas rumah kaca dari sektor sampah di Kota Kendari(6) menyertakan emisi dari pembakaran terbuka pada sebagian sampahnya, sehingga metode pengolahan sampah yang diterapkan ada tiga, landfilling, pengomposan, dan pembakaran terbuka. Landfilling mengemisikan $\mathrm{CH}_{4}$ sebesar $1.470 .889 \mathrm{~kg} /$ tahun, pengomposan mengemisikan $\mathrm{CH}_{4}$ sebesar 187 $\mathrm{kg} /$ tahun serta $\mathrm{N}_{2} \mathrm{O}$ sebesar $12 \mathrm{~kg} /$ tahun. Pembakaran terbuka mengemisikan $\mathrm{CO}_{2}$ sebesar $149.373 \mathrm{~kg} /$ tahun, $\mathrm{CH}_{4}$ sebesar $4.666 \mathrm{~kg} / \mathrm{tahun}$, dan $\mathrm{N}_{2} \mathrm{O}$ sebesar $108 \mathrm{~kg} / \mathrm{tahun}$. Di Yogyakarta, pengelolaan sampah buah di pasar dengan cara anaerobic digestion dilaporkan dapat menurunkan gas rumah kaca sebesar $899 \mathrm{~kg} \mathrm{CO} \mathrm{CO}_{2} \mathrm{eq} / \mathrm{ton}$ sampah buah yang diolah di TPA. Namun, dibandingkan dengan dampak lingkungan lain seperti eutrofikasi, asidifikasi, potensi toksisitas manusia, dan ekotoksisitas air, potensi pemanasan global yang dihasilkan menunjukkan nilai yang paling besar, sehingga perlu dilakukan analisis lebih lanjut agar dapat mengurangi potensi pemanasan global yang terbentuk ${ }^{(7)}$.

Selain gas rumah kaca yang berasal dari landfill, transportasi sampah, pemakaian alat berat, dan proses pengomposan mengemisikan gas-gas lain yang dapat menimbulkan dampak lingkungan seperti asidifikasi dan eutrofikasi. Asidifikasi terjadi ketika terdapat polutan seperti $\mathrm{SO}_{2}, \mathrm{NO}_{x}$, dan $\mathrm{NH}_{3}$ membentuk ion $\mathrm{H}^{+}$di lingkungan yang menyebabkan lingkungan menjadi asam, sedangkan eutrofikasi terjadi karena banyaknya nutrien yang ada di perairan dan menyebabkan terjadinya pergeseran komposisi spesies serta produktivitas biologis, seperti lonjakan alga ${ }^{(8)}$.

Dampak lingkungan dari sebuah produk dapat dihitung dengan Life Cycle Assessment (LCA). Life Cycle Assessment merupakan teknik menilai aspek lingkungan dan dampak potensial suatu produk dengan cara menginventarisasi input dan output-nya, mengevaluasi dampak lingkungannya, dan menginterpretasi hasil dari fase analisis inventory dan penilaian dampak ${ }^{(9)}$. Beberapa kelebihan yang dimiliki LCA di antaranya: 1) LCA menilai sistem dan memberikan hasil analisis yang luas dan lebih komprehensif, 2) LCA menawarkan hasil analisis siklus hidup yang selanjutnya dapat digunakan untuk perbaikan sistem, hasil analisis yang dihasilkan dapat berupa dampak lingkungan maupun dominansi substansi kontributor yang menyebabkan dampak lingkungan itu menjadi tinggi(8), dan 3) secara khusus, LCA dalam pengelolaan limbah menunjukkan manfaat lingkungan yang dapat diperoleh melalui pengelolaan limbah dengan cara tertentu(10).

Studi LCA pada pengelolaan sampah yang dilakukan di Campo Grande, Brazil menunjukkan bahwa penambahan fasilitas Mechanical Biological Treatment (MBT) memberikan hasil yang baik dalam mengurangi dampak lingkungan karena mampu memperbanyak sampah terpilah serta membentuk RDF (Refuse Derived Fuel)(11). Semakin banyak sampah terpilah, semakin mengurangi pemanasan global. Adanya pengolahan sampah dengan $A D$, memberikan hasil positif bagi ketersediaan bahan bakar, terutama untuk pengganti solar kendaraan. Sementara itu, selain memberikan hasil positif pada pengurangan dampak lingkungan, 
pengomposan meningkatkan toksisitas lingkungan dan eutrofikasi dari emisi $\mathrm{NO}_{x}$ ke udara dan $\mathrm{NO}_{3}^{-}$ke lingkungan. LCA dilakukan terhadap beberapa skenario pengolahan sampah di TPA Piyungan Yogyakarta(12). Beberapa metode pengelolaan sampah yang digunakan di antaranya landfilling dengan atau tanpa pemanfaatan energi, insinerasi, gasifikasi, dan anaerobic digestion. Hasil penelitian menunjukkan bahwa pengolahan sampah yang memberikan dampak lingkungan terkecil yaitu dengan landfill dan gasifikasi, dengan penghindaran terhadap dampak potensi pemanasan global, asidifikasi, eutrofikasi, dan potensi pembentukan oksidan fotokimia. Studi LCA dilakukan pula di Kota Nagpur, India Tengah ${ }^{(13)}$. Pengelolaan sampah yang ada di Nagpur belum dilakukan dengan baik. Pengelolaan sampah yang diusulkan dalam studi tersebut di antaranya landfill, pengomposan, Material Recovery Facility (MRF), dan AD. Hasil penelitiannya menunjukkan metode pengolahan sampah yang sesuai meliputi gabungan dari MRF, pengomposan, dan landfill. Adanya MRF membantu memilah sampah sehingga semakin kecil jumlah sampah yang diolah dengan landfill dan mengurangi dampak lingkungan yang ditimbulkan. Material Recovery Facility merupakan fasilitas pemilah sampah campuran yang terdiri atas pemilahan mekanik dan manual, yang memiliki kemampuan pemilahan yang detail(14).

\subsection{Tujuan Penelitian}

Penelitian ini bertujuan menilai dampak lingkungan dari pengelolaan sampah eksisting di TPA Gunung Panggung Kabupaten Tuban Jawa Timur beserta skenario alternatifnya menggunakan LCA.

\section{METODE}

Pengambilan data pada penelitian ini dilakukan pada bulan Mei-Agustus tahun 2019. Data diperoleh dari Dinas Lingkungan Hidup (DLH) dan Dinas Perumahan Rakyat dan Kawasan Permukiman (PRKP) Kabupaten Tuban, dan dilengkapi dengan data-data pendukung dari karya ilmiah yang relevan dengan penelitian ini.

Tahapan dalam LCA terdiri atas penentuan tujuan dan ruang lingkup (goal and scope), penentuan batasan sistem, satuan fungsional, inventory analysis, life cycle impact assessment, dan interpretasi hasil sesuai dengan tujuan digunakan. Terdapat tiga jenis pendekatan dalam analisis LCA berdasarkan fungsinya, yakni: 1) LCA akuntansi yang sesuai untuk digunakan dalam keperluan eco-labelling sebuah produk, 2) stand-alone LCA, digunakan untuk mendeskripsikan produk tunggal, mencari hotspot untuk melakukan evaluasi strategi hingga pelabelan produk, dan 3) change-oriented LCA, digunakan untuk pengembangan produk, pembuatan desain atau proses, atau perbandingan opsi-opsi yang dapat diterapkan di masa depan ${ }^{(8)}$. Berdasarkan tiga jenis pendekatan tersebut, pendekatan change-oriented LCA digunakan dalam penelitian ini, yang membandingkan beberapa skenario pengelolaan sampah dan dipilih satu yang mungkin dapat diterapkan di masa depan.

Pada penelitian ini, disusun tiga skenario alternatif pengelolaan sampah TPA Gunung Panggung untuk selanjutnya dianalisis dampak lingkungannya menggunakan LCA. Pada saat yang sama, LCA juga diterapkan untuk mengevaluasi dampak lingkungan pada kondisi TPA saat ini (eksisting). Tiga skenario yang disusun adalah pengelolaan sampah dengan cara landfill, pengomposan, dan Anaerobic Digestion (AD). Landfilling dan pengomposan telah diterapkan di TPA Gunung Panggung, sementara AD merupakan pengelolaan tambahan dalam skenario alternatif. AD dipilih karena memiliki beberapa kelebihan di antaranya dapat mengurangi kebutuhan lahan landfill, dapat menghasilkan pupuk dan menjadi sumber energi sekaligus, dapat mengurangi pemanasan global dari emisi $\mathrm{CH}_{4}$, dan menghasilkan sumber energi yang dapat diperbarui(15).

Pemilahan sampah disertakan dalam skenario yang diamati dengan persentase yang berbeda-beda, khususnya untuk sampah daun dan sampah makanan. Hal ini dimaksudkan untuk memperbanyak jumlah sampah diolah pada tahap selanjutnya, dalam hal ini pengomposan dan AD. Selain itu, pemilahan sampah juga dimaksudkan untuk mengetahui kaitan pengurangan sampah yang diolah dengan landfill dan dampak lingkungan yang dihasilkan. Pemilahan sampah diasumsikan telah dilakukan dari sumbernya dengan cara meletakkan sampah tertentu dalam wadah tertentu untuk kemudian diangkut pada hari tertentu. Misalnya, sampah daun dan ranting dikumpulkan dalam wadah tertentu dan diangkut setiap hari Senin dan Kamis setiap minggu. Perbedaan persentase sampah terpilah diasumsikan karena adanya perbedaan jumlah pelaku pemilah sampah yang melakukan pemilahan sampahnya sebelum diangkut.

\section{Penentuan Tujuan dan Ruang Lingkup}

Tujuan penerapan LCA dalam penelitian ini yaitu menilai dampak lingkungan dari pengelolaan sampah eksisting di TPA Gunung Panggung Kabupaten Tuban Jawa Timur beserta skenario alternatifnya. Ruang lingkup penelitian ini meliputi pengangkutan sampah dari sumber sampah, pengelolaan sampah di TPA dalam kondisi eksisting (landfill dan pengomposan), dan AD sebagai alternatif tambahan. 
Satuan fungsional yang digunakan dalam penelitian ini yaitu per ton per tahun sampah yang diolah. Batasan sistem dalam penelitian ini terdapat pada Gambar 1.

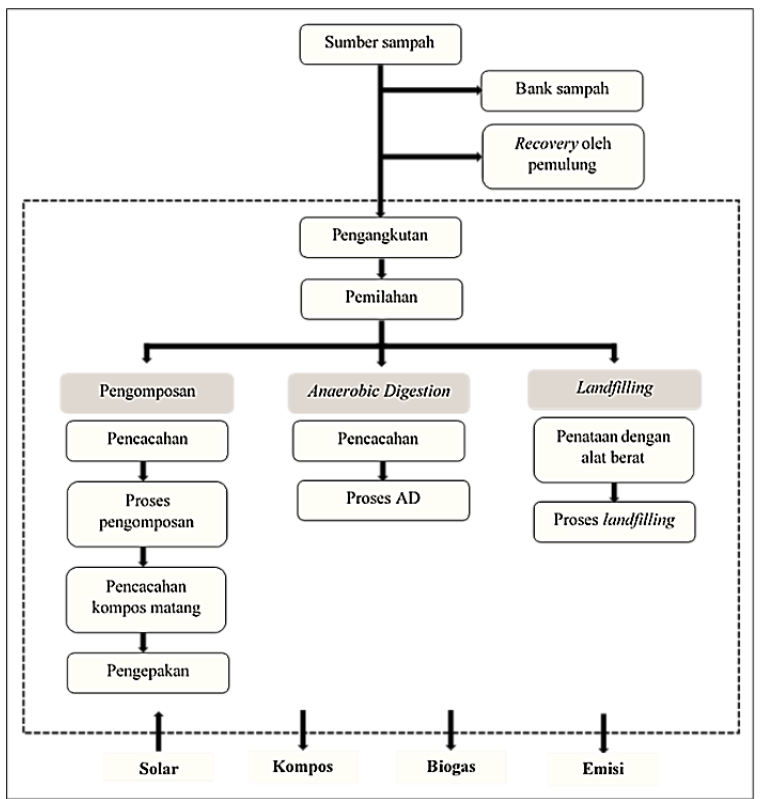

Gambar 1. Batasan sistem

Skenario pengelolaan sampah meliputi skenario eksisting yang merupakan pengelolaan sampah saat ini (landfill dan pengomposan); skenario 1 dengan asumsi sampah telah dipilah $50 \%$ dari sumber, landfill, dan pengomposan; skenario 2 dengan asumsi sampah telah dipilah $60 \%$ dari sumber, landfill, pengomposan, dan $A D$; dan skenario 3 dengan asumsi sampah telah dipilah $70 \%$ dari sumber, landfill, pengomposan, dan AD.

Pengomposan di TPA Gunung Panggung dilakukan dalam bak pengompos. Penyortiran sampah yang akan dikompos dilakukan menggunakan tenaga manusia, begitu pula aktivitas memasukkan sampah ke dalam bak pengompos serta pembalikan kompos. Sebelum dikomposkan, sampah dicacah kemudian disesuaikan kelembapannya dengan ditambahkan air, selanjutnya kompos dimasukkan ke dalam bak pengompos. Kompos matang ditandai dengan warna kompos menjadi hitam atau gelap dan diperoleh dalam kurun waktu sekitar 3-4 bulan. Kompos matang kemudian dicacah lagi untuk mendapatkan ukuran yang homogen.

Sampah yang diolah dengan $A D$ dalam penelitian ini yakni sampah makanan (sampah dapur, sampah buah dan sayur yang berasal dari pasar atau supermarket). Proses fermentasi anaerobik diawali dengan penyortiran bahan yang dilakukan dengan tenaga manusia, selanjutnya bahan dicacah. Bahan yang telah dicacah ditambahkan air dan difermentasikan dalam reaktor.
Penghitungan beban lingkungan dari pengelolaan lindi dari landfill dan penyimpanan digestate dari $A D$ tidak disertakan dalam penelitian ini karena keterbatasan waktu. Selain itu, energi dan emisi tenaga manusia dalam berbagai aktivitas pada proses pengomposan dan $A D$, seperti halnya penyortiran, tidak disertakan. Meskipun energi dari tenaga manusia dapat diketahui, namun emisinya tidak dapat dimasukkan pada analisis impact assessment karena kurangnya informasi ${ }^{(16)}$.

\section{Inventory Analysis}

Tahap inventory analysis merupakan tahap pengumpulan data dan penghitungan input dan output. Inventory analysis meliputi pembuatan diagram alir skenario sistem yang diamati, pengumpulan data semua aktivitas dalam sistem, dan penghitungan beban lingkungan yang ditimbulkan ${ }^{(8)}$. Data yang diperlukan di antaranya: 1) teknis pengelolaan sampah, 2) laju timbulan sampah, 3) komponen dan komposisi sampah, 4) jumlah sampah yang diambil oleh pemulung, 5) rute kendaraan pengangkut sampah, 6) jumlah dan luas daerah pelayanan, 7) kebutuhan bahan bakar alat berat untuk pengelolaan landfill, dan 8) kebutuhan bahan bakar dan air yang dibutuhkan dalam proses pengomposan. Data 1-8 diperoleh dari Dinas Lingkungan Hidup (DLH) dan Dinas Perumahan Rakyat dan Kawasan Permukiman (PRKP) Kabupaten Tuban. Data faktor emisi dan faktor ekuivalensi tahap midpoint maupun endpoint diperoleh dari berbagai sumber yang relevan dengan penelitian ini, meliputi faktor emisi kendaraan pengangkut sampah dari IPCC ${ }^{(23)}$ dan penelitian Börjesson dan Berglund (24); faktor emisi pencacah dari IPCC(23); faktor emisi pengomposan dan landfill dari IPCC(4); faktor emisi $A D$ dari penelitian $\mathrm{Xu}^{(20)}$; faktor emisi pengepakan kompos dari Kementerian Energi dan Sumber Daya Mineral(27); faktor emisi alat berat dari Diaz dan Warith(28); dan faktor ekuivalensi tahap midpoint dan endpoint dari Baumann dan Tillman ${ }^{(8)}, \mathrm{ReCiPe}^{(30)}$, dan Eco-indicator 99(31).

\section{Jumlah Penduduk}

Jumlah penduduk perlu diketahui terlebih dahulu guna menentukan jumlah sampah yang terbentuk pada daerah pelayanan. Berikut adalah persamaan penghitungan jumlah penduduk ${ }^{(17)}$.

$P_{n}=P_{o} \times e^{r . t}$

Keterangan:

$P_{n}$ : jumlah penduduk tahun $n$

$P_{0}$ : jumlah penduduk tahun awal

e : bilangan pokok dari sistem logaritma natural $(2,7182818)$

$\mathrm{t}$ : periode waktu antara tahun dasar dan tahun $\mathrm{n}$ 


\section{Jumlah Penduduk Terlayani}

Jumlah sampah yang terbentuk ditentukan berdasarkan jumlah penduduk dan luas daerah pada kecamatan yang dilayani. Luas daerah pelayanan ditentukan dengan:

Luas rata-rata kecamatan $=$

Luas total daerah pelayanan $\left(\mathrm{km}^{2}\right)-\left(\right.$ Luas Kec. Tuban $\left.\left(\mathrm{km}^{2}\right) \times 95 \%\right)$

Keterangan:

95\% : persentase pelayanan Kecamatan Tuban (diketahui)

15 : jumlah kecamatan yang ingin diketahui luasnya (kecuali Kecamatan Tuban)

Jumlah penduduk terlayani diperoleh dengan mengalikan jumlah penduduk per kecamatan dengan luas kecamatan terlayani.

Jumlah penduduk terlayani

$=$ penduduk per kecamatan (orang $\left./ \mathrm{km}^{2}\right) \times$ luas rata rata kecamatan $\left(\mathrm{km}^{2}\right)$

\section{Jumlah Sampah yang Terbentuk dari Daerah Terlayani}

Jumlah sampah yang terbentuk diperoleh dengan mengalikan jumlah penduduk terlayani dengan laju timbulan sampah.

Jumlah sampah terbentuk

$=$ penduduk terlayani (orang) $\times$

laju timbulan sampah (kg/orang. hari)

Data laju pembentukan sampah sebesar 0,36 $\mathrm{kg} /$ orang.hari merupakan data tahun 2018 oleh DLH, dalam Dokumen Hasil Survei Laju Timbulan Sampah, SRT dan SSRT, Komposisi, serta Potensi Daur Uang di Kabupaten Tuban(18).

\section{Jumlah Bahan Bakar Pengangkutan Sampah}

Jarak tempuh truk pengangkut dihitung sesuai dengan rute kendaraan menggunakan Google Maps. Rute kendaraan diperoleh dari Dinas PRKP dan konsumsi solar per kilometer sebesar $0,53 \mathrm{~L} / \mathrm{km}^{(19)}$. Dengan menyesuaikan jarak tempuh kendaraan dan konsumsi solar per kilometer, kebutuhan bahan bakar dapat diketahui.

Kebutuhan bahan bakar

$=$ jarak tempuh kendaraan $(\mathrm{km}) \times \operatorname{solar}(\mathrm{L} / \mathrm{km})$.

\section{Jumlah Sampah yang Keluar Sistem}

Sampah yang diolah bank sampah dan sampah yang diambil oleh pemulung dianggap sebagai sampah yang keluar sistem. Jumlah sampah yang dikelola bank sampah diasumsikan dengan:

(Jumlah sampah yang diperoleh bank sampah sampel/n) $\times$ Jumlah bank sampah aktif
Keterangan:

$\mathrm{n}$ : jumlah bank sampah sampel (Bank Sampah Gobel, Bank Sampah Mandiri21, dan Bank Sampah Kencana Madya).

Data jumlah sampah yang diambil pemulung diperoleh dari DLH.

\section{Volume Bahan Bakar dan Air yang Digunakan dalam Proses AD}

Volume bahan bakar dalam proses $A D$ digunakan untuk pretreatment sampah dengan cara dicacah. Volume bahan bakar yang dibutuhkan diperoleh dengan:

Volume bahan bakar

$=$ massa bahan baku (ton) $\times$

konsumsi solar per ton bahan (L/ton)

Keterangan:

Konsumsi solar per ton bahan disesuaikan dengan data yang digunakan dalam pencacahan pada proses pengomposan, 2,2 l/ton.

Volume air yang ditambahkan dalam proses $A D$ yakni sebesar $5,49 \mathrm{~m}^{3} /$ ton $\mathrm{VS}^{(20)}$, sementara volatile solid (VS) limbah makanan adalah $26,35 \%$ $\mathrm{wb}^{(21)}$.

Volume air

$=$ massa bahan (ton) $\times 26,35 \% \times 5,49 \mathrm{~m}^{3} /$ ton VS

\section{Penghitungan Emisi Transportasi Pengangkutan Sampah}

Volume bahan bakar transportasi pengangkutan dihitung energinya menggunakan heating value sebesar $0,038 \mathrm{GJ} /(22)$ kemudian dikalikan dengan faktor emisi $\mathrm{CO}_{2}(74.100 \mathrm{~kg} / \mathrm{TJ})$, $\mathrm{CH}_{4}(3,9 \mathrm{~kg} / \mathrm{TJ}), \mathrm{N}_{2} \mathrm{O}(3,9 \mathrm{~kg} / \mathrm{TJ})^{(23)}$ dan $\mathrm{CO}(150$ $\mathrm{mg} / \mathrm{MJ}), \mathrm{NO}_{x}(570 \mathrm{mg} / \mathrm{MJ}), \mathrm{SO}_{2}(2 \mathrm{mg} / \mathrm{MJ})^{(24)}$.

Emisi transportasi $=$ fuel $($ joule $) \times$ faktor emisi

\section{Penghitungan Emisi Pencacahan Bahan Kompos dan AD \\ Emisi dari pencacahan bahan kompos} maupun $A D$ diperoleh dengan mengalikan volume bahan bakar yang telah dikonversi dalam bentuk energi dengan faktor emisi. Faktor emisi pencacahan bahan kompos dan $\mathrm{AD}$ yaitu $\mathrm{CO}_{2}$ $(74.100 \mathrm{~kg} / \mathrm{TJ}), \quad \mathrm{CH}_{4} \quad(3,9 \mathrm{~kg} / \mathrm{TJ}), \quad \mathrm{N}_{2} \mathrm{O} \quad(3,9$ $\mathrm{kg} / \mathrm{TJ})^{(23)}$.

\section{Penghitungan Emisi dari Proses \\ Pengomposan}

Data yang diperlukan dalam penghitungan emisi $\mathrm{CH}_{4}$ dan $\mathrm{N}_{2} \mathrm{O}$ proses pengomposan adalah data jumlah limbah tahunan. Pengomposan dilakukan pada sampah daun atau sampah kebun. Faktor emisi proses pengomposan yaitu $\mathrm{CH}_{4}\left(4 \mathrm{~g} / \mathrm{kg}\right.$ limbah) dan $\mathrm{N}_{2} \mathrm{O}(0,24 \mathrm{~g} / \mathrm{kg} \text { limbah })^{(4)}$. Asumsi kadar air bahan yaitu $60 \%$. Emisi berupa 
$\mathrm{CO}_{2}$ yang merupakan gas biogenic, berasal dari dekomposisi material organik, dikecualikan dalam penghitungan ini. Persamaan berikut digunakan untuk mengestimasikan emisi $\mathrm{CH}_{4}$ dan $\mathrm{N}_{2} \mathrm{O}^{(4)}$.



Keterangan:

M : Massa limbah yang dikompos $(\mathrm{kg})$

$\mathrm{EF}$ : faktor emisi $\mathrm{CH}_{4}$

$10^{-3}$ : konstanta

$\mathrm{R}$ : jumlah $\mathrm{CH}_{4}$ yang di-recovery

Emisi $\mathrm{N}_{2} \mathrm{O}$ tahunan $=(\mathrm{M} \times \mathrm{EF}) \times 10^{-3}$

Keterangan:

M : Massa limbah yang dikompos $(\mathrm{kg})$

$\mathrm{EF}$ : faktor emisi $\mathrm{N}_{2} \mathrm{O}$

$10^{-3}$ : konstanta

Sementara itu, emisi $\mathrm{NH}_{3}$ dari pengomposan dihitung dengan mengalikan persentase $\mathrm{N}$ dalam bahan $(2,25 \%)^{(25)}$, massa bahan $(\mathrm{kg})$, dan persentase emisi $\mathrm{NH}_{3}(6,2 \%)^{(26)}$.

Emisi $\mathrm{NH}_{3}=2,25 \% \times$ massa bahan $(\mathrm{kg}) \times 6,2 \% \ldots$.

\section{Penghitungan Emisi dari Proses Anaerobic Digestion (AD)}

Massa volatile solid (VS) bahan perlu diketahui terlebih dahulu. Persentase VS dalam limbah makanan sebesar $26,35 \% w^{(21)}$. Massa VS bahan dapat diketahui dengan mengalikan massa bahan yang akan diolah (ton) dengan persentase VS (\% wb). Faktor emisi dari proses AD di antaranya: $\mathrm{N}(0,18 \mathrm{~kg} /$ ton $\mathrm{VS}), \mathrm{NH}_{3}(0,15$ $\mathrm{kg} /$ ton VS), dan $\mathrm{P}\left(1,06 \times 10^{-2} \mathrm{~kg} /\right.$ ton VS) ${ }^{(20)}$.

Emisi dari proses AD = massa VS bahan (ton VS) $\times$

faktor emisi (kg/ton VS)

\section{Pembentukan Gas Metana Biogas}

Biogas yang dihasilkan dari 1 ton VS yaitu $591 \mathrm{~m}^{3(20)}$. Angka tersebut dapat digunakan untuk mengetahui gas metana yang terbentuk dari proses $A D$ dengan mengalikan persentase metana yang terkandung dalam biogas yang terbentuk (asumsi kandungan metana 55\%).

\section{Penghitungan Emisi Proses Pengepakan Kompos}

Pengepakan kompos dilakukan menggunakan mesin jahit elektrik. Emisi dari proses pengepakan dapat diketahui dengan mengalikan konsumsi listrik ( $\mathrm{mWh}$ ) dengan faktor emisi penggunaan listrik $\left(\mathrm{CO}_{2} / \mathrm{mWh}\right)$. Faktor emisi gas rumah kaca sistem interkoneksi listrik Jawa, Madura, dan Bali (Jamali) sebesar 0,840 ton $\mathrm{CO}_{2} / \mathrm{mWh}^{(27)}$.

\section{Penghitungan Emisi Bahan Bakar Alat Berat}

Alat berat berupa excavator digunakan untuk mengelola sampah di landfill. Faktor emisi dari bahan bakar alat berat di antaranya: $\mathrm{CO}_{2}$ (3.018,88 g/L), $\mathrm{CO}(0,01 \mathrm{~g} / \mathrm{L}), \mathrm{CH}_{4}(3,63 \mathrm{~g} / \mathrm{L}), \mathrm{NO}_{x}$ $(21,214 \mathrm{~g} / \mathrm{L})$, dan $\mathrm{SO}_{x}(5,75 \mathrm{~g} / \mathrm{L})^{(28)}$. Emisi dari penggunaan alat berat diperoleh dengan mengalikan volume bahan bakar yang digunakan (I) dengan faktor emisinya.

\section{Penghitungan Emisi dari Proses Landfilling}

Diperlukan data komponen sampah beserta persentasenya dan angka-angka default dari IPCC dalam menggunakan metode ini. Seperti halnya pengomposan, penghitungan emisi landfilling memerlukan input data limbah tahunan ${ }^{(4)}$. Emisi berupa $\mathrm{CO}_{2}$ yang merupakan gas biogenic, berasal dari dekomposisi material organik, dikecualikan dalam penghitungan ini.

\section{Life Cycle Impact Assessment (LCIA)}

Data beban lingkungan yang diperoleh pada tahap inventory analysis kemudian diklasifikasi menjadi beberapa kategori dampak lingkungan: pemanasan global, asidifikasi, dan eutrofikasi. Kategori dampak lingkungan yang telah terbentuk dari beberapa beban lingkungan yang berbedabeda dikarakterisasi menggunakan faktor ekuivalensi. Tahapan ini merupakan tahap midpoint yang merupakan tahapan penghubung rantai sebab akibat dari aktivitas yang menyebabkan beban terhadap lingkungan dengan mekanisme lingkungan itu sendiri(29). Tabel angka faktor ekuivalensi beban lingkungan terhadap kategori dampak terdapat pada Tabel 1.

Tabel 1. Tabel faktor ekuivalensi beban lingkungan terhadap kategori dampak ${ }^{(8,30,31)}$

\begin{tabular}{|c|c|c|}
\hline Beban lingkungan & Kategori dampak & Faktor ekuivalensi \\
\hline $\mathrm{CO}_{2}$ & \multirow{5}{*}{ Pemanasan global } & 1 \\
\hline $\mathrm{CH}_{4}$ & & 34 \\
\hline $\mathrm{CH}_{4}$ fosil & & 36 \\
\hline $\mathrm{N}_{2} \mathrm{O}$ & & 298 \\
\hline $\mathrm{CO}$ & & 3 \\
\hline $\mathrm{SO}_{2}$ & \multirow{4}{*}{ Asidifikasi } & 0,45 \\
\hline $\mathrm{NO}_{\mathrm{x}}$ & & 0,14 \\
\hline $\mathrm{NH}_{3}$ & & 0,49 \\
\hline $\mathrm{SO}_{\mathrm{x}}$ & & 1 \\
\hline $\mathrm{NO}_{\mathrm{x}}$ & \multirow{4}{*}{ Eutrofikasi } & 0,13 \\
\hline $\mathrm{NH}_{3}$ & & 0,33 \\
\hline $\mathrm{N}$ & & 0,42 \\
\hline $\mathrm{P}$ & & 0,101 \\
\hline
\end{tabular}


Faktor ekuivalensi asidifikasi $\left(\mathrm{SO}_{2}, \mathrm{NO}_{x}\right.$, dan $\mathrm{NH}_{3}$ ) dan eutrofikasi (P) memiliki nilai spesifik untuk negara Indonesia(30). Setelah diperoleh beban lingkungan dari masing-masing kategori dampak, beban lingkungan tersebut dapat dikelompokkan lagi ke dalam beberapa kategori kerusakan (damage) meliputi kesehatan manusia (human health), kualitas ekosistem (ecosystem quality), dan kelangkaan sumber daya (resource scarcity). Pengelompokan kategori dampak ke dalam tiga kategori area of protection ini disebut tahap endpoint.
Pemanasan global, asidifikasi, dan eutrofikasi hanya berpengaruh pada dua kategori saja yakni kesehatan manusia dan kualitas ekosistem. Kesehatan manusia yang diekspresikan dengan Disability Adjusted Life Year (DALY) dipengaruhi oleh pemanasan global, sedangkan kualitas ekosistem (spesies.tahun/kg stressor) dipengaruhi oleh ketiganya. Berikut ini merupakan faktor karakterisasi untuk masingmasing kategori dampak(Tabel 2) (30).

Tabel 2. Faktor karakterisasi tahap endpoint(30)

\begin{tabular}{|c|c|c|c|c|}
\hline Area of protection & Pemanasan global* & Asidifikasi $^{* \star}$ & Eutrofikasi ${ }^{\star *}$ & Satuan \\
\hline Kesehatan manusia & $9,28 \times 10^{-7}$ & - & - & $\mathrm{DALY} / \mathrm{kg} \mathrm{CO} \mathrm{CO}_{2} \mathrm{eq}$ \\
\hline Ekosistem terestrial (darat) & $2,80 \times 10^{-9}$ & $1,54 \times 10^{-7}$ & - & spesies.tahun/kg stressor ${ }^{* * *}$ \\
\hline Ekosistem akuatik & $7,65 \times 10^{-14}$ & - & $2,49 \times 10^{-8}$ & spesies.tahun/kg stressor ${ }^{* * *}$ \\
\hline \begin{tabular}{ll}
\multicolumn{2}{l}{ Keterangan: } \\
* & dalam jangka waktu 100 tahu \\
$* *$ & spesifik negara Indonesia \\
$* * *$ & stressor berupa $\mathrm{CO}_{2} \mathrm{eq}, \mathrm{SO}_{2} \mathrm{\Theta}$ \\
$(-)$ & faktor karakterisasi terbatas
\end{tabular} & $\begin{array}{l}\text { atau, } \mathrm{PO}_{4}^{3-} \mathrm{eq} \\
\text { la area of protection y }\end{array}$ & tkan & & \\
\hline
\end{tabular}

Perspektif dalam penentuan kerusakan (damage) yang digunakan yaitu hierarkis dengan rentang waktu yang seimbang, 100 tahun (jangka panjang dan pendek). Perspektif hierarkis merupakan perspektif yang direkomendasikan untuk digunakan sebagai metode default( ${ }^{311}$.

\section{Interpretasi Hasil}

Hasil yang diperoleh dari LCIA skenario yang telah dibuat, dilakukan interpretasi agar diperoleh kesimpulan dari penelitian ini.

\section{HASIL DAN PEMBAHASAN}

Jumlah penduduk terlayani TPA Gunung Panggung yaitu 259.021 orang dan jumlah sampah yang dihasilkan per harinya sebesar $93.247,54 \mathrm{~kg}(652.732,76 \mathrm{~kg} / \mathrm{minggu})$. Komposisi sampah di Kabupaten Tuban mayoritas adalah sampah makanan sebesar 58,5\% (Tabel 3). Pengelolaan sampah eksisting di TPA Gunung Panggung yaitu landfill dan pengomposan. Pemilahan sampah untuk pengomposan dilakukan secara manual dan residunya dibuang ke landfill. Sampah yang masih dapat dimanfaatkan diambil oleh pemulung.

Tabel 3. Komposisi sampah di Kabupaten Tuban ${ }^{(18)}$

\begin{tabular}{clc}
\hline No. & Komponen sampah & Persentase \\
\hline 1 & Sampah makanan & $58,5 \%$ \\
\hline 2 & Sampah kebun/taman & $15,3 \%$ \\
\hline 3 & Plastik & $11,0 \%$ \\
\hline 4 & Kertas & $5,8 \%$ \\
\hline 5 & Kayu & $0,1 \%$ \\
\hline 6 & Kain/tekstil & $1,6 \%$ \\
\hline 7 & Karet & $0,05 \%$ \\
\hline 8 & Kulit & $0,0 \%$ \\
\hline 9 & Logam & $0,2 \%$ \\
\hline 10 & Gelas/kaca & $1,3 \%$ \\
\hline 11 & Diapers & $4,4 \%$ \\
\hline 12 & Lain-lain & $1,7 \%$ \\
\hline & Total & $100,0 \%$ \\
\hline
\end{tabular}




\subsection{Inventory Analysis}

Input sumber daya per ton sampah yang diolah terdapat pada Tabel 4. Beban lingkungan diperoleh dari data input dan output dalam inventory analysis. Tabel input sumber daya masing-masing skenario terdapat pada Tabel 5. Perbedaan jumlah sampah pada masing-masing skenario disebabkan karena adanya asumsi bahwa sampah dipilah dalam jumlah tertentu, skenario 1 (dipilah 50\%), skenario 2 (dipilah 60\%), dan skenario $3(70 \%)$. Jumlah sampah yang dikompos pada skenario 2 tidak diberi tambahan sampah daun dari sampah terpilah, sehingga jumlah sampah yang dikomposkan pada skenario
2 sama dengan skenario eksisting. Namun, dalam skenario 2 ini, sampah makanan diolah menggunakan AD. Sementara itu, sampah yang dikomposkan pada skenario 1 dan 3 berasal dari jumlah yang sama dengan skenario eksisting $(1.800 \mathrm{~kg})$ ditambah dengan sampah daun yang telah terpilah, sehingga jumlahnya lebih besar dibanding skenario eksisting dan skenario 2. $A D$ dilakukan hanya pada skenario 2 dan 3, sehingga tidak ada input sumber daya pada skenario eksisting dan skenario 1. Jumlah sampah dan bahan bakar pada proses landfill semakin berkurang pada setiap skenario karena adanya pengurangan jumlah sampah yang seharusnya diolah dengan landfill.

Tabel 4. Input sumber daya per ton sampah yang diolah

\begin{tabular}{ccc}
\hline Aktivitas & Jenis sumber daya & Input per ton sampah \\
\hline Transportasi & Solar pengangkutan sampah & $5,5 \mathrm{~L}$ \\
\hline \multirow{2}{*}{ Pengomposan } & Solar pencacah & $2,2 \mathrm{~L}$ \\
\cline { 2 - 3 } & Air & $38,9 \mathrm{~L}$ \\
\cline { 2 - 3 } & Listrik & $1,33 \mathrm{kwh}$ \\
\hline \multirow{2}{*}{ AD } & Solar pencacah & $2,2 \mathrm{~L}$ \\
\cline { 2 - 3 } & Air & $1.450 \mathrm{~L}$ \\
\hline Landfill & Solar alat berat & $0,87 \mathrm{~L}$ \\
& \multirow{2}{*}{ Sumber: Hasil perhitungan } \\
\end{tabular}

Tabel 5. Input sumber daya masing-masing skenario

\begin{tabular}{lcccc}
\hline \multicolumn{1}{c}{ Jenis sumber daya } & Skenario eksisting & Skenario 1 & Skenario 2 & Skenario 3 \\
\hline Sampah terbentuk $(\mathrm{kg})$ & $652.732,76$ & $652.732,76$ & $652.732,76$ & $652.732,76$ \\
\hline Sampah masuk bank sampah $(\mathrm{kg})$ & 6.720 & 6.720 & 6.720 & 6.720 \\
\hline Sampah diambil pemulung $(\mathrm{kg})$ & 21.000 & 21.000 & 21.000 & 21.000 \\
\hline Sampah untuk kompos $(\mathrm{kg})$ & 1.800 & $51.799,33$ & 1.800 & $71.799,06$ \\
\hline Kompos matang $(60 \%)$ susut 40\% $(\mathrm{kg})$ & 1.080 & $31.079,60$ & 1.080 & $43.079,44$ \\
\hline Bahan bakar pencacahan $(\mathrm{L})$ & 6,4 & 182,33 & 6,4 & 252,73 \\
\hline Air $(\mathrm{L})$ & 70 & $2.014,99$ & 70 & $2.792,98$ \\
\hline Listrik $(\mathrm{kWh})$ & 1,44 & 41,34 & 1,44 & 57,30 \\
\hline Sampah untuk AD $(\mathrm{kg})$ & 0 & 0 & $229.226,69$ & $267.431,14$ \\
\hline Bahan bakar pencacahan $(\mathrm{L})$ & 0 & 0 & 504,30 & 588,35 \\
\hline Air $(\mathrm{L})$ & 0 & 0 & 331.596 & 386.825 \\
\hline Sampah untuk landfill $(\mathrm{kg})$ & $623.212,76$ & $573.213,43$ & $393.986,07$ & $285.782,56$ \\
\hline Bahan bakar alat berat $(\mathrm{L})$ & 535,96 & 492,96 & 338,83 & 245,77 \\
\hline
\end{tabular}

Sumber: DLH dan hasil perhitungan

Pemilahan sampah diasumsikan telah dilakukan dari sumbernya dengan cara meletakkan sampah tertentu dalam wadah tertentu untuk kemudian diangkut pada hari tertentu. Misalnya, sampah daun dan ranting dikumpulkan dalam wadah tertentu dan diangkut setiap hari Senin dan Kamis setiap minggu. Pemilahan sampah dilakukan terutama untuk sampah daun dan sampah makanan. Hal ini dimaksudkan untuk memperbanyak jumlah sampah diolah pada tahap selanjutnya, dalam hal ini pengomposan dan AD. Selain itu, pemilahan sampah juga dimaksudkan untuk mengetahui kaitan pengurangan sampah yang diolah dengan landfill dan dampak lingkungan yang dihasilkan. Semakin banyak sampah yang terpilah menunjukkan semakin banyak masyarakat melakukan pemilahan sampah dari sumber.

Sampah yang masuk bank sampah dan diambil pemulung mengurangi jumlah sampah yang diolah dengan landfill, pengomposan, dan AD. Jumlah sampah yang masuk bank sampah dan diambil pemulung yaitu $27.720 \mathrm{~kg} /$ minggu. 


\subsection{Life Cycle Impact Assessment (LCIA)}

Kategori dampak yang digunakan dalam penelitian ini adalah pemanasan global, asidifikasi, dan eutrofikasi. Langkah pertama yang dilakukan dalam melakukan LCIA yaitu mengelompokkan substansi emisi ke dalam kategori dampak yang telah dipilih, misalnya $\mathrm{CO}_{2}$ digolongkan ke dalam pemanasan global. Langkah ini disebut dengan klasifikasi(8). Langkah selanjutnya yaitu karakterisasi ke tahap midpoint.
Proses karakterisasi adalah langkah kuantitatif untuk menghitung emisi yang bermacam-macam pada kategori dampak agar memiliki unit yang sama menggunakan equivalency factor, misalnya dampak pemanasan global ditunjukkan dengan ekuivalensi terhadap $\mathrm{CO}_{2}\left(\mathrm{CO}_{2} \mathrm{eq}\right)$.

Pemanasan global mengalami penurunan di setiap skenario, skenario eksisting 6.379.506,17 $\mathrm{kg} \mathrm{CO}$ eq, skenario $15.939 .251,94 \mathrm{~kg} \mathrm{CO}$ eq, skenario $24.305 .971,18 \mathrm{~kg} \mathrm{CO} 2 \mathrm{eq}$, dan skenario $33.344 .001,50 \mathrm{~kg} \mathrm{CO}$ eq (Gambar 2).

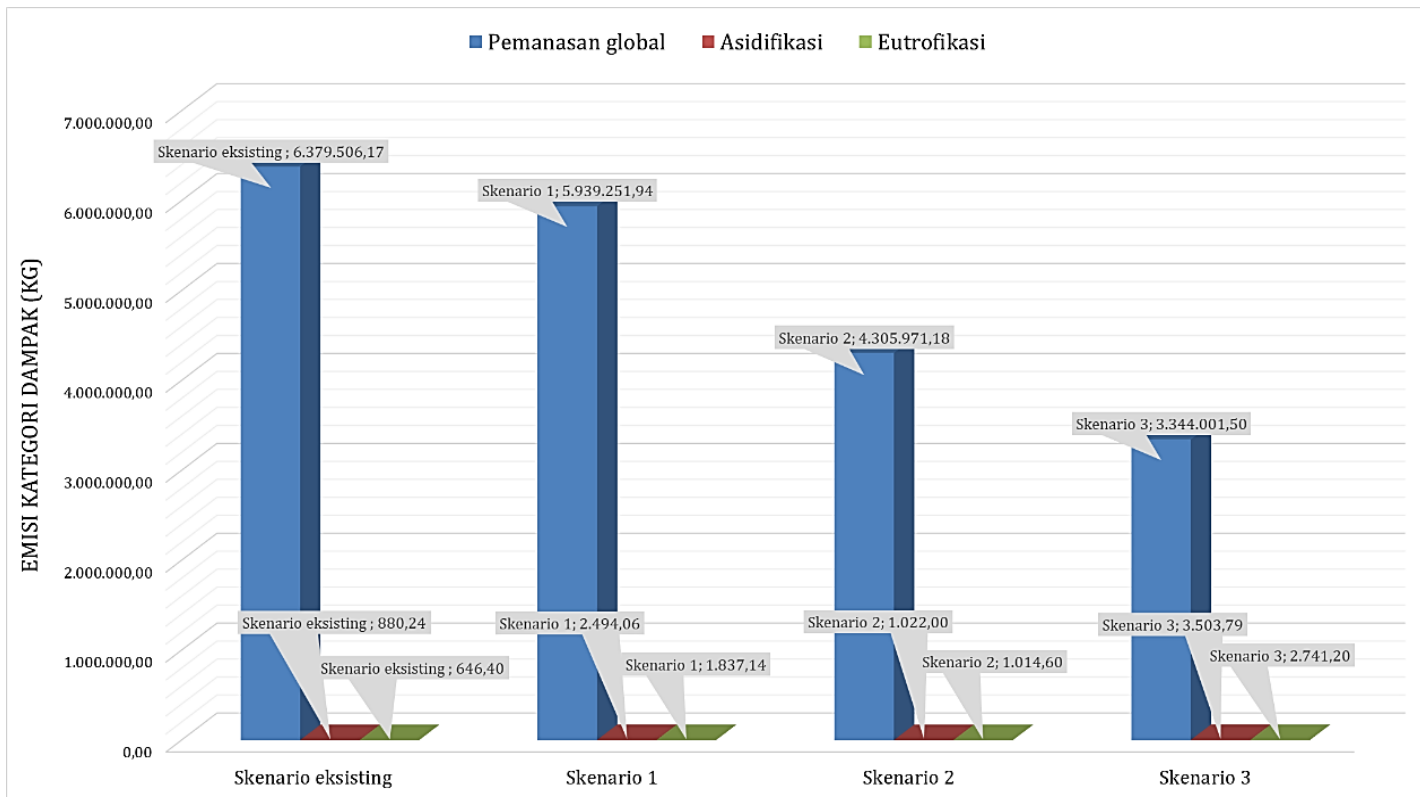

Gambar 2. Grafik perbandingan emisi dari masing-masing skenario

Asidifikasi dan eutrofikasi mengalami fluktuasi dari satu ke skenario lain, hal ini karena adanya perbedaan jumlah input pada masingmasing skenario, terutama pada bahan pengomposan dan AD. Asidifikasi dan eutrofikasi pada skenario eksisting dan skenario 2 relatif lebih rendah dibanding skenario 1 dan 3 . Skenario 3 menunjukkan emisi eutrofikasi tertinggi, yakni
$2.741,72 \mathrm{~kg} \mathrm{PO} 4^{3}$ eq karena banyaknya bahan yang diolah dengan cara pengomposan dan $A D$.

Kerugian akibat adanya dampak lingkungan diklasifikasikan ke dalam dua area of protection, kesehatan manusia dan kualitas ekosistem. Dengan pengelompokan ini, data yang diperoleh dapat lebih mudah dipahami. Kerugian akibat pemanasan global, asidifikasi, dan eutrofikasi terdapat pada Tabel 6.

Tabel 6. Kerugian pada kesehatan manusia dan kualitas ekosistem

\begin{tabular}{ccccccc}
\hline $\begin{array}{c}\text { Kategori } \\
\text { dampak }\end{array}$ & $\begin{array}{c}\text { Area of } \\
\text { protection }\end{array}$ & $\begin{array}{c}\text { Skenario } \\
\text { eksisting }\end{array}$ & Skenario 1 & Skenario 2 & Skenario 3 & Satuan \\
\hline \multirow{2}{*}{$\begin{array}{c}\text { Kesehatan } \\
\text { manusia }\end{array}$} & $\mathbf{5 , 9 2}$ & 5,51 & 4,00 & 3,10 & DALY \\
\cline { 2 - 7 } global & $\begin{array}{l}\text { Ekosistem } \\
\text { terestrial }\end{array}$ & $\mathbf{0 , 0 1 8}$ & 0,017 & 0,012 & 0,009 & spesies.tahun \\
\cline { 2 - 7 } & $\begin{array}{l}\text { Ekosistem } \\
\text { akuatik }\end{array}$ & $\mathbf{0 , 0 0 0 0 0 0 4 9}$ & 0,00000045 & 0,00000033 & 0,00000026 & spesies.tahun \\
\hline Asidifikasi & $\begin{array}{l}\text { Ekosistem } \\
\text { terestrial }\end{array}$ & $\mathbf{0 , 0 0 0 1 4}$ & 0,00038 & 0,00016 & $\mathbf{0 , 0 0 0 5 4}$ & spesies.tahun \\
\hline Eutrofikasi & $\begin{array}{l}\text { Ekosistem } \\
\text { akuatik }\end{array}$ & $\mathbf{0 , 0 0 0 0 1 6}$ & 0,000046 & 0,000025 & $\mathbf{0 , 0 0 0 0 6 8}$ & spesies.tahun \\
\hline
\end{tabular}




\subsection{Interpretasi Hasil}

Dampak lingkungan yang paling besar dalam penelitian ini yaitu pemanasan global (Gambar 2), baik pada skenario eksisting maupun pada ketiga skenario alternatif. Asidifikasi dan eutrofikasi berbeda-beda tergantung dari jumlah input yang digunakan. Dampak lingkungan yang telah diperoleh pada tahap midpoint dapat diamati dominansi emisinya secara lebih detail berdasarkan aktivitas yang ada di dalamnya.
Salah satu cara yang dapat digunakan untuk mengamati aktivitas yang memberikan efek yang menonjol yaitu analisis dominansi. Analisis dominansi digunakan untuk mengetahui bagian dari siklus hidup yang memiliki dampak lingkungan terbesar, dengan mengamati emisi atau dampak lingkungan pada masing-masing aktivitas dalam siklus hidup( ${ }^{(8)}$.

Skenario eksisting menunjukkan dampak terbesar pada pemanasan global yang berasal dari aktivitas landfill (Gambar 3).

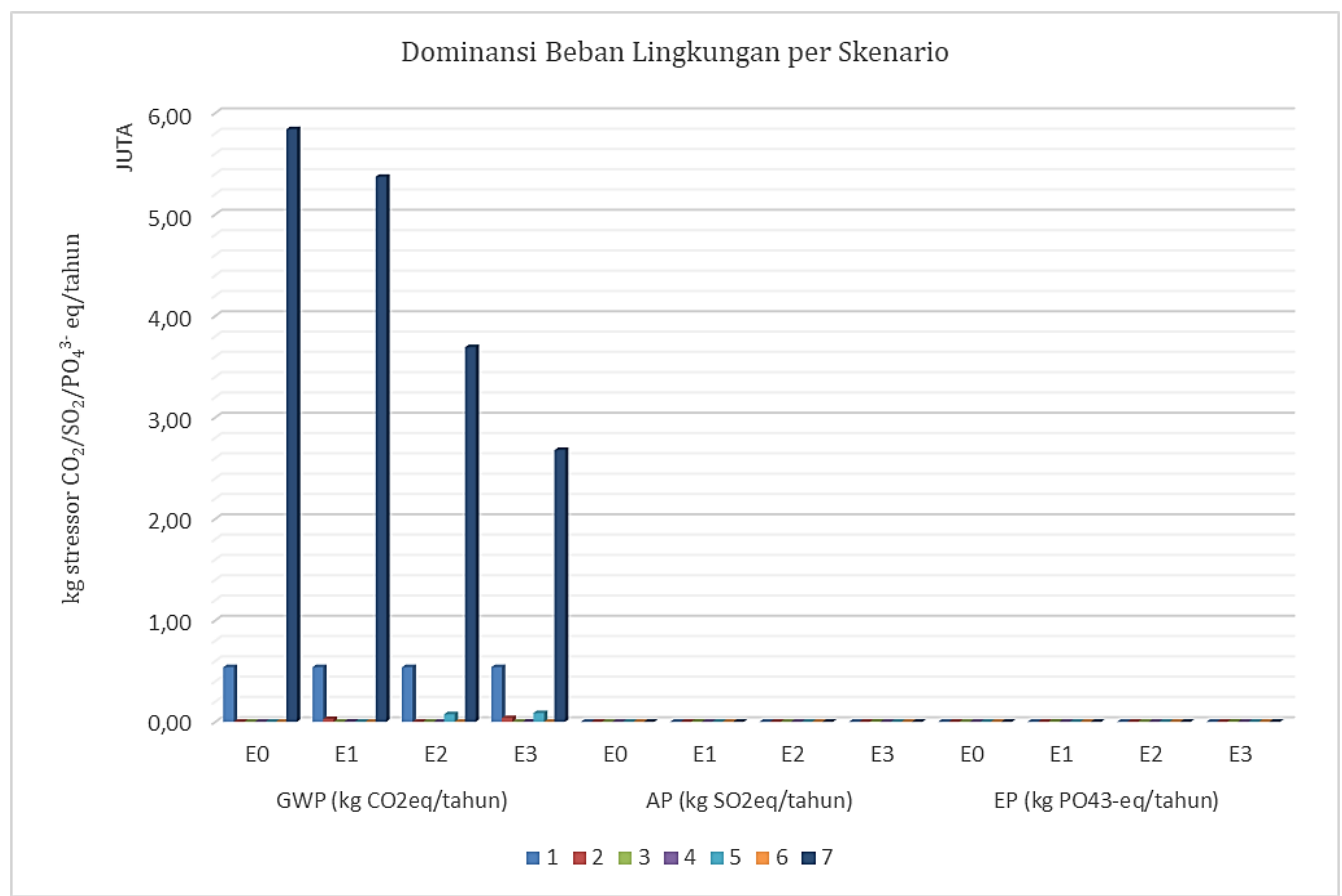

Gambar 3. Grafik dominansi beban lingkungan masing-masing skenario

1: Transportasi, 2: Pencacahan bahan kompos, 3: Proses pengomposan,

4: Pengepakan kompos, 5: Pencacahan bahan AD, 6: Proses AD, 7: Landfilling;

E0: Skenario eksisting, E1: Skenario 1, E2: Skenario 2, E3: Skenario 3

Penimbunan sampah mengemisikan $\mathrm{CH}_{4}$ yang berkontribusi pada pemanasan global (5.839.661,43 kg CO 2 eq/tahun). Emisi $\mathrm{CO}_{2}$ dari transportasi, pencacahan bahan kompos, serta emisi $\mathrm{CO}_{2}$ dari penggunaan alat berat turut memberikan kontribusi kepada dampak pemanasan global. Sama halnya dengan skenario eksisting, proses landfilling menunjukkan dampak lingkungan yang besar pada pemanasan global pada skenario 1 (5.371.154,95 kg CO2eq/tahun) (Tabel 7).

Pemanasan global meningkat pada proses pencacahan bahan kompos. Peningkatan dampak lingkungan asidifikasi juga terjadi pada skenario 1 ini, kontributor terbesar pada asidifikasi skenario 1 berasal dari pengangkutan $(573,28 \mathrm{~kg}$ $\left.\mathrm{SO}_{2} \mathrm{eq} / \mathrm{tahun}\right)$ dan landfill $(223,50 \mathrm{~kg}$ $\mathrm{SO}_{2} \mathrm{eq} /$ tahun).
Skenario 2 memiliki tambahan pengelolaan sampah berupa $A D$. Pencacahan bahan yang digunakan untuk $A D$ menambah beban pemanasan global sebesar 74.377,36 kg $\mathrm{CO}_{2}$ eq/tahun. Meskipun jumlah sampah yang dikompos lebih sedikit, 71.799,06 kg untuk kompos dan 267.431,14 kg untuk AD, beban eutrofikasi pengomposan lebih besar dibanding emisi beban eutrofikasi proses AD. Beban eutrofikasi dari proses pengomposan dan $A D$ yaitu $1.717,20 \mathrm{~kg} \mathrm{PO}_{4}{ }^{3-} \mathrm{eq} / \mathrm{tahun}$ dan $462,28 \mathrm{~kg}$ $\mathrm{PO}_{4}{ }^{3-}$ eq/tahun, berturut-turut. Salah satu permasalahan dalam proses pengomposan adalah hilangnya nitrogen dalam kompos. Nitrogen dapat teremisikan ke lingkungan terutama dalam bentuk $\mathrm{NH}_{3}\left({ }^{(31)}\right.$ dan $\mathrm{NH}_{3}$ merupakan salah satu kontributor beban eutrofikasi(33). 
Tabel 7. Dominansi beban lingkungan per skenario

\begin{tabular}{|c|c|c|c|c|c|c|c|c|c|c|c|c|}
\hline \multirow{2}{*}{ Aktivitas } & \multicolumn{4}{|c|}{ GWP (kg CO${ }_{2}$ eq/tahun) } & \multicolumn{4}{|c|}{$\mathrm{AP}$ (kg SO${ }_{2}$ eq/tahun) } & \multicolumn{4}{|c|}{$\mathrm{EP}\left(\mathrm{kg} \mathrm{PO}_{4}{ }^{3-} \mathrm{eq} /\right.$ tahun$)$} \\
\hline & E0 & E1 & E2 & E3 & E0 & E1 & E2 & E3 & E0 & E1 & E2 & E3 \\
\hline 1 & $538.839,60$ & $538.839,60$ & $538.839,60$ & $538.839,60$ & 573,28 & 573,28 & 573,28 & 573,28 & 526,47 & 526,47 & 526,47 & 526,47 \\
\hline 2 & 934,79 & $26.892,74$ & 934,79 & $37.274,57$ & 0,00 & 0,00 & 0,00 & 0,00 & 0,00 & 0,00 & 0,00 & 0,00 \\
\hline 3 & 7,95 & 558,69 & 7,95 & 756,27 & 63,95 & $1.841,18$ & 63,95 & $2.549,78$ & 43,07 & $1.239,98$ & 43,07 & $1.717,20$ \\
\hline 4 & 62,40 & $1.805,96$ & 62,40 & $2.502,76$ & 0,00 & 0,00 & 0,00 & 0,00 & 0,00 & 0,00 & 0,00 & 0,00 \\
\hline 5 & 0,00 & 0,00 & $74.377,36$ & $86.773,61$ & 0,00 & 0,00 & 0,00 & 0,00 & 0,00 & 0,00 & 0,00 & 0,00 \\
\hline 6 & 0,00 & 0,00 & 0,00 & 0,00 & 0,00 & 0,00 & 231,14 & 269,30 & 0,00 & 0,00 & 396,47 & 462,28 \\
\hline 7 & $5.839 .661,43$ & $5.371 .154,95$ & $3.691 .749,08$ & $2.677 .854,69$ & 243,00 & 223,50 & 153,62 & 111,43 & 76,86 & 70,69 & 48,59 & 35,25 \\
\hline Total & $6.379 .506,17$ & $5.939 .251,94$ & $4.305 .971,18$ & $3.344 .001,50$ & 880,24 & $2.637,97$ & $1.022,00$ & $3.503,79$ & 646,40 & $1.837,14$ & $1.014,60$ & $2.741,20$ \\
\hline
\end{tabular}

\section{Keterangan:}

1: Transportasi

. Pencacahan bahan kompos

GWP: Global warming potential (potensi pemanasan global)

3: Proses pengomposan

AP: Acidification potential (potensi asidifikasi)

4: Pengepakan kompos

5: Pencacahan bahan AD

EP: Eutrophication potential (potensi eutrofikasi)

6: Proses AD

E0: Skenario eksisting

E1: Skenario 1

E2: Skenario 2

E3: Skenario 3 
Berdasarkan dampak pemanasan global yang ditimbulkan, skenario 3 menunjukkan beban paling kecil. Namun, dampak asidifikasi dan eutrofikasi menunjukkan nilai tertinggi yang berasal dari proses pengomposan. Seperti disebutkan sebelumnya bahwa salah satu permasalahan dalam proses pengomposan adalah hilangnya nitrogen dalam bentuk $\mathrm{NH}_{3}$. Pembalikan yang terlalu sering dilaporkan menghasilkan kadar $\mathrm{N}$ yang lebih rendah di akhir masa pengomposan, dibanding kompos yang frekuensi pembalikannya sedikit(34-36).

Hilangnya nitrogen dapat diatasi dengan mengontrol frekuensi pembalikan. Pengomposan pasif yang jarang dilakukan pembalikan menunjukkan emisi $\mathrm{NH}_{3}$ yang lebih sedikit. Pembalikan akan mengubah posisi yang semula di bawah menjadi ke daerah permukaan tumpukan kompos. Bagian bawah kompos yang berpindah ke permukaan mendapat pasokan oksigen yang cukup sehingga menjadi lebih aktif karena aktivitas mikroorganisme. Aktivitas ini membuat suhu di lingkungan permukaan lebih tinggi dan menjadikan $\mathrm{NH}_{3}$ mudah teremisikan(32). Selain pembalikan, pemberian cover pada tumpukan kompos dapat mencegah $\mathrm{NH}_{3}$ teruapkan(32). Manajemen produksi kompos yang meliputi kualitas dan komposisi limbah, frekuensi pencampuran bahan, serta pemantauan kelembapan dan temperatur sangat berpengaruh terhadap emisi dan produk yang dihasilkan(37). Aktivitas pencampuran bahan akan menciptakan proses aerasi pada kompos sehingga menyediakan oksigen dan memicu emisi $\mathrm{NH}_{3}$, dengan memperhatikan frekuensi pencampuran bahan, emisi $\mathrm{NH}_{3}$ mengalami penurunan sebesar 52 kali dan menurunkan asidifikasi dan eutrofikasi masing-masing sebesar 209\% dan $45 \%$ (37).

Ketiga dampak lingkungan di atas dapat menyebabkan kerugian pada kesehatan manusia dan kualitas ekosistem. Pemanasan global berdampak pada kesehatan manusia dan kualitas ekosistem, sementara asidifikasi dan eutrofikasi hanya berpengaruh pada kualitas ekosistem yang direpresentasikan dengan kepunahan spesies hewan dan tumbuhan. Merujuk Tabel 6, pemanasan global sangat terlihat pengaruhnya pada kesehatan manusia, terutama skenario eksisting. Kesehatan manusia berisiko mengalami kerugian selama 5,92 DALY yang artinya akibat pemanasan global yang disebabkan oleh pengelolaan sampah skenario eksisting, manusia dapat mengalami kecacatan selama 5,92 tahun dalam hidupnya. Penyakit yang menyebabkan kerugian pada manusia yakni penyakit yang berkaitan dengan peningkatan suhu. Beberapa vektor penyakit menunjukkan perubahan siklus hidupnya akibat meningkatnya suhu lingkungan. Sebagai contoh penyakit malaria dengan vektor nyamuk Anopheles. Nyamuk Anopheles hidup di daerah panas dan lembap. Kemunculannya terutama ketika pancaroba terjadi. Namun, karena adanya curah hujan yang tidak teratur, nyamuk Anopheles dapat muncul sepanjang tahun seperti dilaporkan di Afrika Selatan dan Afrika Timur pada tahun $1988^{(38)}$.

Pemanasan global memengaruhi ekosistem baik terestrial maupun akuatik. Organisme terestrial baik tumbuhan maupun hewan dapat terkena dampak dari pemanasan global. Di Indonesia pemanasan global berdampak pada komunitas terumbu karang di Gili Matra, Nusa Tenggara Barat. Peningkatan suhu yang terjadi pada tahun 2016 menyebabkan terjadinya pemutihan pada beberapa genus terumbu karang yang rentan seperti Acropora, Heliopora, Stylophora, dan Pocillopora. Terumbu karang merupakan habitat bagi berbagai ikan. Pemutihan terumbu karang berpengaruh pada berkurangnya kelimpahan dan biomassa ikan yang hidup di sekitar terumbu karang(39).

Nilai kepunahan spesies yang dihasilkan dalam penelitian ini tidak menunjukkan nilai yang sangat besar, baik terestrial maupun akuatik yang disebabkan oleh pemanasan global, asidifikasi, dan eutrofikasi. Kepunahan spesies akibat pemanasan global semakin menurun seiring berkurangnya sampah yang diolah dengan landfill. Sementara kepunahan spesies akibat asidifikasi dan eutrofikasi meningkat seiring banyaknya sampah yang diolah dengan pengomposan dan AD.

Kepunahan spesies karena asidifikasi terjadi pada tumbuhan berpembuluh, terutama pada lingkungan tropis-subtropis. Tumbuhan gurun dan semak belukar yang hidup di daerah kering memiliki kemampuan adaptasi yang baik terhadap perubahan lingkungan dibanding tumbuhantumbuhan tropis-subtropis. Tumbuhan gurun didominasi oleh rerumputan dan semak, sementara hutan tropis-subtropis didominasi oleh tumbuhan berdaun lebar, yang tumbuhan ini memiliki sensitivitas lebih tinggi dibanding tumbuhan berukuran kecil(40).

Eutrofikasi atau pengayaan nutrisi di perairan akibat adanya substansi fosfat mengakibatkan ketidakseimbangan komposisi organisme di perairan tersebut. Terjadinya eutrofikasi di suatu perairan menyebabkan kandungan oksigen terlarut menurun. Oksigen diperlukan untuk mendegradasi bahan organik yang masuk ke perairan sebagai substansi eutrofikasi. Sementara itu, oksigen juga diperlukan untuk organisme lain yang ada di perairan sehingga terjadi adanya kompetisi terhadap oksigen. Perairan dengan kandungan fosfat dan nitrogennya tinggi, kadar oksigen terlarut di dalamnya cenderung rendah(41).

Di sisi lain, eutrofikasi menyebabkan kelimpahan mendadak pada tumbuhan air. 
Kelimpahan terhadap tumbuhan air tertentu, misalnya plankton, dapat menguntungkan ikan jenis tertentu, khususnya ikan herbivor. Eutrofikasi di perairan menyebabkan kelimpahan alga yang tinggi dan menyebabkan biomassa ikan menjadi tinggi pula, terutama apabila disertai dengan suhu lingkungan yang tinggi. Dengan ini, pemanasan global menjadi satu faktor yang membuat beban lingkungan semakin tinggi(42).

Meskipun demikian, LCIA hingga tahap endpoint memiliki banyak ketidakpastian yang disebabkan oleh banyaknya tahap yang perlu dilewati hingga mencapai tahap akhir(29). Penggabungan berbagai efek pembentuk damage pada endpoint memang menghasilkan data yang mudah dipahami, namun tidak dapat dipisahkan dari ketidakpastian data itu sendiri(43). Terutama untuk dampak kerugian karena pemanasan global, terdapat beberapa hambatan dalam memodelkan dampak kesehatan akibat gas rumah $\mathrm{kaca}^{(31)}$, dua di antaranya yaitu 1) perubahan iklim tidak langsung memberikan pengaruhnya pada masa kini, melainkan pada dekade mendatang dan setelahnya, 2) gas rumah kaca yang teremisikan di Eropa dapat memberikan kerugian di seluruh dunia(31). Poin kedua tentunya berlaku di mana pun. Dua poin yang terakhir disebutkan memberikan tambahan kontribusi terhadap ketidakpastian pada tahap endpoint, khususnya kerugian pada kesehatan manusia karena pemanasan global.

\section{KESIMPULAN}

Analisis LCA pada penelitian ini menunjukkan dampak lingkungan pemanasan global merupakan dampak lingkungan tertinggi pada masing-masing skenario pengelolaan sampah di TPA Gunung Panggung, terutama pada skenario eksisting, yaitu 6.379.506,17 kg $\mathrm{CO}_{2} \mathrm{eq} /$ tahun. Aktivitas yang memberikan dampak besar pada pemanasan global yaitu landfill. Sementara itu, asidifikasi dan eutrofikasi tertinggi yaitu pada skenario 3 yang berasal dari proses pengomposan. Upaya mitigasi untuk skenario 3 adalah meminimalkan emisi $\mathrm{NH}_{3}$ yang timbul dari proses pengomposan sampah daun dengan cara mengontrol pembalikan atau pemberian cover. Kerugian akibat dampak lingkungan sangat terlihat pada kesehatan manusia, 5,92 DALY yang disebabkan oleh pemanasan global. Kerugian pada kualitas ekosistem tidak menunjukkan nilai yang besar.

\section{PERSANTUNAN}

Penulis mengucapkan terima kasih kepada Dinas Lingkungan Hidup (DLH) dan Dinas Perumahan Rakyat dan Kawasan Permukiman (Dinas PRKP) Kabupaten Tuban atas penyediaan informasi dan data-data yang diperlukan pada penelitian ini.

\section{DAFTAR PUSTAKA}

1. Badan Pusat Statistik. (2019). Kabupaten Tuban dalam Angka 2019. In Tuban: BPS Kabupaten Tuban.

2. Gaol, M. L., \& Warmadewanthi, I. D. A. A. (2017). Prediksi dampak lingkungan pengelolaan sampah di TPA Jabom, Kabupaten Sidoarjo. Jurnal Teknik ITS, 6(2), 2-7.

3. Hapsari, D. S. A., \& Herumurti, W. (2017). Laju timbulan dan komposisi sampah rumah tangga di Kecamatan Sukolilo Surabaya. Jurnal Teknik ITS, 6(2), C421-C424.

4. Intergovernmental Panel on Climate Change. (2006). Guidelines for National Greenhouse Gas Inventories. Volume 5. Waste. Retrieved January 27, 2021, from https://www.ipccnggip.iges.or.jp/public/2006gl/vol5.html

5. Kiswandayani, A. V., Susanawati, L. D., \& Wirosoedarmo, R. (2016). Komposisi sampah dan potensi emisi gas rumah kaca pada pengelolaan sampah domestik: Studi kasus TPA Winongo Kota Madiun. Jurnal Sumberdaya Alam dan Lingkungan, 2(3), 917.

6. Chaerul, M., Dirgantara, G. G., \& Akib, R. (2016). Prediction of greenhouse gasses emission from municipal solid waste sector in Kendari City, Indonesia. Jurnal Manusia Dan Lingkungan, 23(1), 42-48. https://doi.org/https://doi.org/10.22146/jml.18 772

7. Marendra, F., Rahmada, A., Prasetya, A., Cahyono, R. B., \& Ariyanto, T. (2018). Kajian dampak lingkungan pada sistem produksi listrik dari limbah buah menggunakan life cycle assessment. Jurnal Rekayasa Proses, 12(2), 85-97. https://doi.org/10.22146/jrekpros.36425

8. Baumann, H., \& Tillman, A. M. (2004). The hitch hiker's guide to LCA: an orientation in life cycle assessment methodology and application.

9. International Organization of Standardization. (1997). ISO 14040:2006 Environmental management - Life cycle assessment Principles and framework.

10. Cherubini, F., Bargigli, S., \& Ulgiati, S. (2009). Life cycle assessment (LCA) of waste management strategies: landfilling, sorting plant and incineration. Energy, 34(12), 21162123.

https://doi.org/10.1016/j.energy.2008.08.023

11. Lima, P. D. M., Olivo, F., Paulo, P. L., Schalch, V., \& Cimpan, C. (2019). Life cycle 
assessment of prospective MSW management based on integrated management planning in Campo Grande, Brazil. Waste Management, 90, 59-71. https://doi.org/10.1016/j.wasman.2019.04.03 5

12. Gunamantha, M., Fandeli, C., Tandjung, S. D., \& Sarto. (2010). Life cycle assessment pilihan pengelolaan sampah: studi kasus wilayah Kartamantul Provinsi D.I. Yogyakarta. Jurnal Manusia Dan Lingkungan, 17(2), 78-88. https://doi.org/10.22146/jml.18706

13. Khandelwal, H., Thalla, A. K., Kumar, S., \& Rakesh, K. (2019). Life cycle assessment of municipal solid waste management options for India. Bioresource Technology, 288(March), 121515.

https://doi.org/10.1016/j.biortech.2019.12151 5

14. Tchobanoglous, G., \& Kreith, F. (2002). Handbook of Solid Waste Management (2nd Edition). https://doi.org/10.1036/0071356231

15. Wilkie, A. C. (2005). Anaerobic digestion: biology and benefits. Dairy Manure Management: Treatment, Handling, and Community Relations, 63-72.

16. Ghaderpour, O., Rafiee, S., Sharifi, M., \& Mousavi-Avval, S. H. (2018). Quantifying the environmental impacts of alfalfa production in different farming systems. Sustainable Energy Technologies and Assessments, 27(April 2017), 109-118. https://doi.org/10.1016/j.seta.2018.04.002

17. Badan Pusat Statistik. (2010). Pedoman Penghitungan Proyeksi Penduduk dan Angkatan Kerja. In Jakarta: Badan Pusat Statistik.

18. Dinas Lingkungan Hidup. (2018). Dokumen Hasil Survei Laju Timbulan Sampah, SRT dan SSRT, Komposisi, serta Potensi Daur Ulang di Kabupaten Tuban.

19. Anggun, T. Y., \& Munawar, A. (2014). Analisis sistem transportasi sampah Kota Tuban menggunakan dynamic programming. Envirotek: Jurnal Ilmiah Teknik Lingkungan, 6(1), 45-52. Retrieved from http://eprints.upnjatim.ac.id/6822/

20. Xu, C., Shi, W., Hong, J., Zhang, F., \& Chen, W. (2015). Life cycle assessment of food waste-based biogas generation. Renewable and Sustainable Energy Reviews, Vol. 49, pp. 169-177. Elsevier Ltd. https://doi.org/10.1016/j.rser.2015.04.164

21. Zhang, R., El-Mashad, H. M., Hartman, K.,
Wang, F., Liu, G., Choate, C., \& Gamble, P. (2007). Characterization of food waste as feedstock for anaerobic digestion. Bioresource Technology, 98(4), 929-935. https://doi.org/10.1016/j.biortech.2006.02.039

22. McDougall, F. R., White, P. R., Franke, M., \& Hindle, P. (2001). Integrated solid waste management: a life cycle inventory. Second edition. In Blackwell Science. Wiley. https://doi.org/10.1002/9780470999677

23. Intergovernmental Panel on Climate Change. (2006). Guidelines for National Greenhouse Gas Inventories. Volume 2. Energy. Retrieved January 27, 2021, from https://www.ipccnggip.iges.or.jp/public/2006gl/vol2.html

24. Börjesson, P., \& Berglund, M. (2006). Environmental systems analysis of biogas systems - Part I: Fuel-cycle emissions. Biomass and Bioenergy, 30(5), 469-485. https://doi.org/10.1016/j.biombioe.2005.11.01 4

25. Menikpura, S. N. M., Gheewala, S. H., \& Bonnet, S. (2012). Sustainability assessment of municipal solid waste management in Sri Lanka: problems and prospects. Journal of Material Cycles and Waste Management, 14(3), $181-192$. https://doi.org/10.1007/s10163-012-0055-z

26. Andersen, J. K., Boldrin, A., Christensen, T. H., \& Scheutz, C. (2010). Mass balances and life-cycle inventory for a garden waste windrow composting plant (Aarhus, Denmark). Waste Management and Research, 28(11), 1010-1020.

https://doi.org/10.1177/0734242X10360216

27. Kementerian Energi dan Sumber Daya Mineral. (2016). Surat Penyampaian Faktor Emisi GRK Sub Sektor Ketenagalistrikan. http://jcm.ekon.go.id/en/uploads/files/Docume nt\%20JCM/Reference/Surat_Penyampaian_ Faktor_Emisi_GRK_Subsektor_Ketenagalistri kan.pdf

28. Diaz, R., \& Warith, M. (2006). Life-cycle assessment of municipal solid wastes: Development of the WASTED model. Waste Management, 26(8), 886-901. https://doi.org/10.1016/j.wasman.2005.05.00 7

29. Bare, J. C., Hofstetter, P., Pennington, D. W., \& Udo de Haes, H. A. (2000). Life cycle impact assessment workshop summary. Midpoints versus endpoints: the sacrifices and benefits. International Journal of Life Cycle Assessment, 5(6), 319-326. https://doi.org/10.1007/BF02978665

30. Huijbregts, M. A. J., Steinmann, Z. J. N., 
Elshout, P. M. F. M., Stam, G., Verones, F., Vieira, M. D. M., van Zelm, R. (2016). ReCiPe 2016. In National Institute for Public Health and the Environment. Retrieved from https://www.rivm.nl/bibliotheek/rapporten/201 6-0104.pdf

31. Goedkoop, M., \& Spriensma, R. (2000). The Eco-indicator 99. A damage-oriented method for life cycle impact assessment. Methodology Report (Vol. https://doi.org/10.3370/lca.3.32

32. Hao, X., \& Benke, M. B. (2008). Nitrogen transformation and losses during composting and mitigation strategies. Dynamic Soil, Dynamic Plant, 2(1), 10-18.

33. Strandroff, H. K., Hoffmann, L., Schmidt, A., \& Technology, F. (2005). Impact categories, normalization and weighting in LCA. In Danish Ministry of The Environment. Environmental Protection Agency. (Vol. 78).

34. Ogunwande, G. A., Ogunjimi, L. A. O., \& Fafiyebi, J. O. (2008). Effects of turning frequency on composting of chicken litter in turned windrow piles. International Agrophysics, 22(2), 159-165.

35. Parkinson, R., Gibbs, P., Burchett, S., \& Misselbrook, T. (2004). Effect of turning regime and seasonal weather conditions on nitrogen and phosphorus losses during aerobic composting of cattle manure. Bioresource Technology, 91(2), 171-178. https://doi.org/10.1016/S09608524(03)00174-3

36. Tiquia, S. M., Tam, N. F. Y., \& Hodgkiss, I. J. (1997). Effects of turning frequency on composting of spent pig-manure sawdust litter. Bioresource Technology, 62, 37-42.

37. Quirós, R., Villalba, G., Muñoz, P., Colón, J., Font, X., \& Gabarrell, X. (2014). Environmental assessment of two home composts with high and low gaseous emissions of the composting process. Resources, Conservation and Recycling, 90, 9-20.

https://doi.org/10.1016/j.resconrec.2014.05.0 08

38. Duarsa, A. B. S. (2008). Dampak pemanasan global terhadap risiko terjadinya malaria. Jurnal Kesehatan Masyarakat Andalas, 2(2), 181. https://doi.org/10.24893/jkma.2.2.181185.2008

39. Setiawan, F., Muttaqin, A., Tarigan, S., Muhidin, M., Hotmariyah, M., Sabil, A., \& Pinkan, J. (2017). Pemutihan karang akibat pemanasan global tahun 2016 terhadap ekosistem terumbu karang: studi kasus di TWP Gili Matra (Gili Air, Gili Meno, dan Gili Trawangan) Provinsi NTB. Journal of Fisheries and Marine Research, 1(2), 39-54. https://doi.org/10.21776/ub.jfmr.2017.001.02. 1

40. Azevedo, L. B., Van Zelm, R., Hendriks, A. J., Bobbink, R., \& Huijbregts, M. A. J. (2013). Global assessment of the effects of terrestrial acidification on plant species richness. Environmental Pollution, 174, 10-15. https://doi.org/10.1016/j.envpol.2012.11.001

41. Alfionita, A. N. A., Patang, P., \& Kaseng, E. S. (2019). Pengaruh eutrofikasi terhadap kualitas air di Sungai Jeneberang. Jurnal Pendidikan Teknologi Pertanian, 5(1), 9-23. https://doi.org/10.26858/jptp.v5i1.8190

42. Bouraï, L., Logez, M., Laplace-Treyture, C., \& Argillier, C. (2020). How do eutrophication and temperature interact to shape the community structures of phytoplankton and fish in lakes? Water 12(3). https://doi.org/10.3390/w12030779

43. De Schryver, A. M. (2011). Value choices in life cycle impact assessment. Retrieved from http://www.ru.nl/publish/pages/556452/2010d eschryver_phdthesis_11jan2011.pdf 